\title{
MENGAJAR BAHASA INGGRIS DI MASA PANDEMI COVID-19 : REFLEKSI DI MI NU ROWOLAKU KABUPATEN PEKALOGAN
}

\author{
Nur Hikmah ${ }^{1}$ \\ Mahasiswa S1 Tadris Bahasa Inggris \\ Fakultas Tarbiyah dan Ilmu Keguruan (FTIK) \\ IAIN Pekalongan \\ * email : nh632567@,gmail.com
}

Informasi Artikel

Diterima Redaksi : 21 Desember 2020

Revisi Akhir : 02 Januari 2021

Diterbitkan Online : 28 Januari 2021

Kata Kunci:

mengajar, bahasa inggris, anak-anak, guru, kreatif.

\section{PENDAHULUAN}

COVID-19 telah memberikan dampak terhadap pendidikan di Indonesia. Pada empat bulan pertama masa darurat pandemi COVID-19 pendidikan di semua level dilaksanakan secara daring. Namun, di masa new nomal ini, ada beberapa sekolah yang melaksanakan pembelajaran secara tatap walaupun hanya tiga hari dalam seminggu dan tetap memperhatikan protokol kesehatan. Proses peralihan dari daring ke tatap muka ini nampaknya membuat siswa merasa kurang bersemangat untuk mengikuti pembelajaran tatap muka karena mereka sudah merasa nyaman dengan belajar daring. Jika dalam sistem daring mereka bisa belajar sambil bermain di luar rumah tanpa mendapat teguran dari guru namun di dalam sistem tatap muka ini pembelajaran tidak bisa ditingalkan serta anak-anak mendapatkan pengawawasan langsung dari guru.

Selama masa pandemi, anak-anak tetap belajar dengan memperhatikan protokol kesehatan. Kenyataan di lapangan menunjukkan bahwa masih ada anak-anak
Abstrak

Penelitian ini menjelaskan narasi pengalaman mengajar bahasa inggris pada masa darurat pandemi COVID-19. Pengalaman pribadi mengajar bahasa inggris kepada anak-anak sebagai salah satu program kerja kuliah kerja nyata $(\mathrm{KKN})$ direkrut menjadi penelitian naratif ini. Hasil penelitian menunjukkan bahwa guru harus kreatif dalam mengajar bahasa inggris bagi anak-anak sehingga mereka tidak merasa bosan dalam belajar. Guru yang kreatif akan mampu membuat proses belajar mengajar menjadi menyenangkan di masa pandemi covid-19 ini sehingga anak-anak merasa senang dalam belajar

yang tidak berangkat sekolah padahal mereka sudah mengetahui bahwa pembelajaran dilaksanakan secara tatap muka di sekolah. Selain itu, proses peralihan ini membuat anak-anak belum siap jika menerima materi yang banyak. Hal ini berdampak pada anak-anak yang terlihat tidak memperhatikan pelajaran. Dalam hal ini, guru harus bisa menjalin kedekatan dengan siswa untuk mengetahui karakteristik mereka. Dengan mengetahui karakteristik anak-anak, guru bisa merancang metode pembelajaran yang tepat..

Adaptasi dan inovasi pembelajaran harus dilakukan oleh guru (Puspitasari, Rahayu \& Rohmatunnazilah, 2020) Guru harus beradaptasi kembali dengan anakanak dengan menyesuaikan psikologis mereka. Namun, guru juga harus berinovasi agar anak-anak tertarik untuk mengikuti pembelajaran. Salah satu wujud inovasi guru adalah dengan mengembangkan metode pembelajaran yang kreatif agar minat anak-anak dalam belajar bangkit kembali. Kurangnya minat 
dalam belajar ini terlihat dalam pelajaran bahasa inggris. Di dalam kurikulum 2013, bahasa inggris sebagai bahasa asing masuk ke dalam mata pelajaran muatan lokal yang mana dalam satu minggu hanya ada satu pertemuan (Permendikbud 81A tahun 2013). Dengan waktu yang singkat ini, seharusnya guru harus bisa memaksimal proses pembelajaran dengan maksimal agar tujuan pembelajaran tercapai. Mata pelajaran bahasa inggris untuk jenjang sekolah dasar bertujuan untuk mengembangkan kompetensi berkomunikasi berbicara secara lisan dalam tindakan keseharian di sekolah. Namun kenyataannya, pembelajaran bahasa inggris untuk sekolah dasar hanya menekankan pada menghafal kosakata saja. Guru bahasa inggris masih menggunakan metode tradisional dalam mengajar bahasa inggris (Sartika, 2017).

Young learners atau pelajar muda dengan usia mulai dari 7-9 tahun (Pinter, 2011). young learners itu memiliki karakteristik yang unik. Beberapa karakteristik tersebut adalah (Harmer, J 2007) :

- Young learners belajar dari lingkungan sekitar baik secara langsung maupun tidak

- Pemahaman mereka lebih mendalam jika mereka melihat, mendengar, menyentuh daripada sekadar penjelasan materi saja

- Pembelajaran yang abstrak tidak cocok bagi mereka

- Mereka lebih suka pelajaran yang berbicara tentang dirinya sebagai topik utama dan meresponnya

- Mereka suka menemukan sesuatu, membuat atau menggambar sesuatu, berimajinasi, perpindah dari satu tempat ke tempat lain, dan menyelesaikan puzzle.

- Mereka mudah bosan

- Antusias dalam belajar bahasa inggris
- Perhatian mereka terhadap
pelajaran sangat pendek

Sebagai upaya memahami karakteristik mereka dan memaksimalkan proses pembelajaran, guru harus bisa membuat model pembelajaran yang kreatif. Model pembelajaran termasuk di dalamnya kemampuan guru untuk meningkatkan motivasi belajar, menyelesaikan masalah, menjali hubungan baik, menggunakan teknik mengajar tertentu (Putra, 2012).

Teaching english to young learners (TEYL) berkembang dengan pesat di berbagai tempat, salah satunya di MI NU Rowolaku, Kec. Kajen, Kab. Pekalongan. Pembelajaran bahasa inggris masih eksis walaupun di masa pandemi COVID-19. Namun sayangnya, hal ini tidak didukung oleh kompetensi guru yang mumpuni. Guru di sekolah ini masih mengajar dengan cara tradisional. Anak-anak kelas 3 harus menghafalkan beberapa kosakata yang ada. Padahal anak-anak di usia ini mempunyai daya konsentrasi yang rendah dan ingatan yang pendek (Ersoz A, 2007). Jika anakanak masih menghafalkan kosakata maka anak-anak belum mengetahui objek atau gambar nyata dari kosakata yang mereka sudah hafalkan. Adanya permasalahan tersebut, maka perlu adanya penelitian agar hal tersebut bisa teratasi.

Berdasarkan permasalahan diatas, penulis mengadakan suatu program kerja yang disebut dengan Home Visit. Home Visit adalah salah satu program kerja Kuliah Kerja Nyata berupa pendampingan belajar bahasa inggris untuk anak-anak MI. Pendampingan belajar ini berpindah tempat dari satu rumah siswa ke rumah siswa yang lainnya. Melalui home visit ini, peneliti menjadi lebih dekat dengan anak-anak dan lebih mendalam mengetahui karakter mereka sehingga dalam menyusun metode pembelajaran lebih mudah. Dengan adanya home visit ini, minat anak-anak dalam belajar bahasa inggris semakin meningkat. 
Penelitian tentang pendampingan belajar selama masa darurat 19 telah banyak dilakukan oleh beberapa peneliti. Pendampingan belajar adalah sebuah usaha untuk mendampingi anak-anak dalam proses belajar (Dwi, 2018). Tri, Hariyani, Roslida (2020) dalam sebuah penelitiannya yang berjudul pendampingan belajar di rumah bagi siswa sekolah dasar terdampak COVID-19 menyatakan bahwa pendampingan belajar sebagai upaya mengatasi kendala dalam proses belajar mempunyai dampak positif bagi siswa dan orang tua.

Penelitian yang serupa, Eka, Ainur, Laura (2002) dalam penelitiannya tentang pendampingan bimbingan bahasa inggris. Objek dari penelitian ini adalah anak-anak SMP. Hasil penelitian menunjukkan bahwa mereka sangat antusias dalam mengikuti pendambingan bimbingan belajar inggris. Hal ini menunjukkan bahwa mereka mempunyai keinginan untuk meningkatkan kemampuan bahasa inggris mereka.

Selain itu, ada penelitian dari Kevin, Kartika, dan Nuryunita (2020) yang menekankan pada metode mendongeng dalam pendampingan belajar. Hasil penelitian menunjukkan bahwa metode mendongeng sebagai media pembelajaran terbukti mampu meningkatkan tingkat berpikir kritis siswa.

Slamet Basuki (2020) dalam penelitiannya yang berjudul Model Penugasan Belajar di Rumah yang Menyenangkan Bagi Siswa Di Masa Pandemi COVID-19 menunjukan bahwa 92,33 model penugasan yang menyenangkan. Tujuan dari penelitian ini adalah untuk memberikan ide serta gambaran tentang model penugasan yang kreatif dan menyenangkan.

Agus Santoso dan Yuni Rusmawati (2019) menginventigasi tentang pendampingan belajar siswa di rumah melalui kegiatan bimbingan belajar di desa Guci Karanggeneng, Lamongan. Tujuan dari penelitian ini adalah untuk memberikan gambaran tentang proses pendambingan belajar melalui bimbel. Melalui bimbingan belajar ini, motivasi dan prestasi siswa mengalami perkembangan yang baik.

Muhammad Ichsan Siregar (2018) dalam artikelnya yang berjudul pendampingan pendidikan anak sekolah dasar di SD N 24 Rambutan Desa Durian Gadis menjelaskan deskripsi tentang pendambingan belajar yang dilaksanakan di desa Durian Gadis. Melalui pendambingan ini, pendidikan anak menjadi lebih baik dan masyarakat sadar akan pentingnya pendidikan.

N.W.S Damayanti, I Nengah Suecca, Linda Sekar Utami (2020) mengatakan bahwa pendambingan belajar untuk menumbuhkan motivasi belajar siswa serta membantu orang tua dalam mendidik dan mengajar anaknya.

Achmad Hidayatullah melakukan pendampingan pendidikan anak di kelurahan Genteng Surabaya selama 30 hari. Hal ini berdampak positif bagi orang tua agar mempunyai waktu luang dan mengontrol anak untuk belajar.

Wasilatul Munawarah melakukan penelitian tentang pendampingan belajar di rumah tingkat SD untuk meningkatkan vocabulary siswa dalam bahasa inggris dengan menggunakan media shapor. Dengan menggunakan media shapor tujuan dari pembelajaran dapat tercapai yaitu vocabulary anak-anak dapat meningkat dengan pesat.

Sujarwo dan Akhiruddin (2020) melaksakan pendampingan pembelajaran ekstrakulikuler bahasa inggris di sekoalah inpres Gowa. Pendampingan ini bertujuan untuk menciptakan suasana pembelajaran bahasa inggris yang menyenangkan. Dengan adanya pendampingan yang menyenangkan ini, hasil listening siswa meningkat menjadi $81,6 \%$ dan speaking $82,3 \%$.

Sri Endang Kusmaryati, Slamet Utomo, Titis Sulistyowati (2019) juga melaksanakan pendampingan pembelajaran 
kosakata bahasa inggris di SD 2 Panjang Kudus dengan permainan guessing games. Tujuan pendampingan ini adalah untuk menyediakan pengajaran bahasa inggris yang menyenangkan. Dengan menggunakan guessing games, kosakata bahasa inggris anak meningkat.

Penelitian ini bertujuan untuk menarasikan pengalaman mengajar bahasa inggris untuk anak-anak selama masa pandemi COVID-19 di MI NU Rowolaku. Program mengajar bahasa inggris ini merupakan salah satu program kerja Kuliah Kerja Nyata Dari Rumah (KKN DR) yang di jalankan oleh peneliti. Melalui program ini, diharapkan bisa membantu anak-anak yang kesulitan dalam belajar bahasa inggris sehingga mereka tidak merasa bosan untuk belajar.

Penelitian ini menggunakan jenis penelitian naratif bertujuan untuk mengeksplor pengalaman pribadi peneliti selama mengajar bahasa inggris di masa pandemi COVID-19 secara langsung (Clandinin \& Huber, 2010). Dalam penelitian ini, pengalaman pribadi mengajar bahasa inggris selama pandemi COVID-19 dinarasikan. Cerita tersebut berguna untuk mengkonstruksi praktik bermakna (best practice) mengajar bahasa inggris di masa pandemi COVID-19 yang telah terlaksana sebagai acuan untuk mengajar bahasa inggris di masa yang akan datang. Satu guru bahasa inggris di MI NU Rowolaku bersedia menjadi partisipan dalam penelitian ini. Pengumpulan data dilakukan dengan teknik wawancara langsung kepada partisipan. Pertanyaan wawancara adalah tentang fokus materi pembelajaran bahasa inggris di kelas tiga MI NU Rowolaku dan juga metode yang digunakan dalam mengajar bahasa inggris.

\section{METODE}

Mengajar bahasa inggris untuk usia anak-anak merupakan hal menyenangkan namun juga menantang. Hal yang menyenangkan karena pada usia ini tingkah mereka sangat menghibur tapi juga menantang karena mereka susah untuk dikendalikan. Bahasa inggris merupakan mata kuliah muatan lokal dimana anak-anak hanya mendapatkannya satu kali dalam seminggu. Materi bahasa inggris kelas tiga secara keseluruhan menekankan pada penguasaan kosakata. Kosakata adalah inti dari mengajar dan belajar bahasa inggris. Kosakata berperan penting dalam penguasaan empat keterampilan bahasa yaitu berbicara, mendengarkan, menulis, dan tata bahasa atau grammar yang memberikan kontribusi yang baik kepada pembelajar untuk menunjukan atau praktik keterampilan mereka. Kata adalah bentuk dasar dari kalimat yang menjadi inti dari komunikasi baik verbal maupun non verbal. Penguasaan kosakata yang baik akan memungkinkan seseorang untuk berkomunikasi kepada orang lain secara efektif. Ini sejalan dengan linguist, David Wilkins mengatakan bahwa "tanpa tata bahasa sedikit yang bisa disampaikan, tanpa kosakata tidak ada yang bisa tersampaikan" (Thornury, 2002).

Anak-anak menganggap bahwa bahasa inggris adalah mata pelajaran yang sulit. Mereka umumnya tidak mengetahui bentuk konkret dari kosakata yang mereka hafalkan. Jika mereka mengetahui bentuk konkretnya, mereka akan mudah untuk mengingatnya. Situasi ini dialami oleh anak-anak di MI NU Rowolaku yang dibuktikan dengan observasi ketika siswa diminta untuk memegang salah satu bagian tubuhnya, terkadang mereka salah memegangnya. Ini karena mereka hanya diminta untuk menghafal tanpa mengetahui bentuk konkretnya.

Buku pegangan yang digunakan adalah Speed Up English 3 New Edition terbitan Yudhistira dengan tahun terbit 2010. Di dalam buku ini ada enam bab. Dalam satu bab selalu terdapat kosakata baru yang terkait dengan materi. Banyaknya kosakata 
tergantung materi yang diajarkan. Tingkat kesulitannya pun berbeda dari mulai kosakata yang mereka sudah ketahui sampai yang anak-anak belum mereka ketahui. Jika anak dalam satu bab belum mampu menghafal, maka dalam pertemuan selanjutnya jumlah kosakata yang mereka hafalkan pun akan bertambah.

Mempertimbangkan hal tersebut, peneliti memberikan sebuah solusi agar pembelajaran kosakata bahasa inggris di MI NU Rowolaku tidak merasa membosankan dan agar anak-anak mengetahui benda konkret dari kosakata yang mereka hafalkan. Dalam kondisi seperti inilah, kretivitas guru di butuhkan. Dari sinilah, peneliti mencoba mengembangkan kreativitasnya untuk membantu anakanak agar mudah dalam belajar bahasa inggris. Pembelajaran bahasa inggris yang kreatif akan lebih menyenangkan bagi anak-anak apalagi dimasa pandemi COVID-19 seperti sekarang ini. Beberapa strategi diaplikasikan dalam pembelajaran kosakata ini. Tujuannya adalah agar anakanak tidak bosan.

\section{HASIL DAN PEMBAHASAN}

Home visit merupakan salah satu program kerja kuliah kerja nyata $(\mathrm{KKN})$ yang menjadi wadah bagi anak-anak untuk belajar bahasa inggris. Program ini berjalan tiga hari dalam seminggu dan bersifat sukarela. Lokasi yang berpindah pindah dari satu rumah siswa ke rumah siswa lainnya. Lokasi yang selalu berpindah ini memberi peluang bagi anak-anak untuk mengetahui lingkungan sekitarnya. Khususnya bagi peneliti, peneliti menjadi lebih dekat dengan orang tua anak-anak dan mengetahui kondisi mereka di rumah. Selama pandemi covid-19, para pendidik baiknya tidak hanya mengandalkan pertemuan di dalam maupun di luar rungan saja namun juga melakukan kunjungan ke rumah anakanak sebagai wujud kepedulian terhadap pendidikan mereka.
Pengalaman ini merupakan pengalaman pertama mengajar bahasa inggris untuk anak-anak MI di tengah pandemi covid-19. Metode yang digunakan oleh peneliti sebelumnya masih monoton seperti metode ceramah, menulis, dan menghafalkan. Dengan menggunakan metode yang monoton itu, peneliti cukup susah mengendalikan anak-anak. Mereka terlihat ramai dan tidak memperhatikan pelajaran sama sekali. Barangkali mereka merasa bosan mengikuti pelajaran selama masa pandemi covid-19.

Setelah mengetahui kondisi anank-anak, peneliti merencanakan beberapa strategi yang ada diterapkan. Ini disesuaikan dengan karakteristik anak. Beberapa starategi pembelajaran tersebut adalah sebagai berikut :

1. Menggambar

Manfaat menggambar bagi anak-anak secara garis besar yaitu : 1). Menggambar sebagai alat bercerita (bahasa visual/bentuk),2) Menggambar sebagai media mencurahkan perasaan, 3). Menggambar sebagai alat bermain, 4). Menggambar melatih ingatan, 5). Menggambar melatih berpikir komprehensif (menyeluruh), 6).Menggambar sebagai media sublimasi perasaan, 7). Menggambar melatih keseimbangan, 8). Menggambar mengembangkan kecakapan emosional, 9). Menggambar melatih kreativitas anak, 10). Usia anak-anak adalah usia dengan imajinasi yang tinggi. Jadi, pada usia ini biarkan anaka-anak mengekspresikan gagasannya. Salah satu sarana untuk mengekspresikannya adalah dengan menggambar. Menggambar adalah memvisualisasikan apa yang ada dipikiran ke dalam bentuk gambar. Hubungannya dengan belajar kosakata adalah anak-anak menggambar kosakata yang sudah mereka hafalkan. Dengan menggambar objek sesuai dengan kosakata yang sudah dihafalkan memudahkan anak-anak untuk mengingat 
serta mengetahui objek nyatanya. Melalui menggambar ini pula, melatih anak-anak untuk dapat meningkatkan imajinasi, kreativitas, kerja sama, kepedulian, dan percaya diri imereka.

Ketika menggambar anak-anak terlihat antusias. Mereka menggambar sambil membayangkan objek benda yang ada dipikiran mereka kemudiannya memvisualisasikan ke dalam gambar. Selama menggambar mereka saling bertukar pikir dan saling berbagi jika ada salah satu diantara mereka ada yang tidak memilki perlengkapan menggambar. Hasil gambaran mereka berbeda satu dengan yang lainnya, namun mereka tidak saling mengejek.

Setelah mereka telah selesai menggambar, peneliti bertanya kepada anak-anak tentang gambarannya beserta kosakata dalam bahasa inggrisnya. Jawaban anak-anak cukup baik. Mereka mampu mengetahui kosakata beserta objek bendanya.

\section{Menempel}

Menempel adalah strategi pembelajaran kosakata dengan menempelkan kosakata sesuai dengan objekya. Tahapan dalam menempel adalah sebagai berikut :

- Anak-anak berbaris maju secara bergantian mengambil kertas berisi kosakata

- Anak - anak yang sudah mendapatkan kertas kosakata kemudian menempelkannya ke temannya menjadi model

- Setelah semuanya tertempel, guru kemudian mengoreksi bersama

\section{Lagu}

Mendengarkan musik memiliki berapa manfaat salah satunya dapat meningkatkan fungsi otak kita bila dihubungkan dengan belajar bahasa Inggris. Melalui metode bernyanyi diharapkan mampu menarik minat anak untuk melakukan kegiatan pembelajaran Bahasa Inggris terutam penguasaan kosakata dengan menyenangkan dan tanpa beban. Dengan membuat anak menyukai metode pembelajaran yang digunakan, diharapkan proses pembelajaran berjalan dengan baik sehingga anak tidak merasa jenuh, bosan dan sulit untuk menguasai kosakata. Ketika anak sudah tertarik untuk melakukan pembelajaran dengan menggunakan metode bernyanyi maka anak akan mudah dalam mengikuti setiap tahapan pembelajaran maka anak akan mudah untuk menguasai dan menghafal kosakata bahasa Inggris.

Keuntungan mengajarkan bahasa Inggris menggunakan nyanyian :

- Melalui lagu akan memotivasi anak untuk lebih senang mempelajari bahasa Inggris.

- Dengan menyanyi anak menjadi senang dan lebih mudah dalam memahami materi ajar yang disampaikan. Kemampuan guru dalam memilih lagu dan menciptakan gerakan yang sesuai dengan usia perkembangan anak akan berdampak pula terhadap berhasilnya proses pembelajaran bahasa Inggris pada anak usia dini.

- Melalui nyanyian dan kegiatan pembelajaran yang bervariasi, pendidik dapat menumbuhkan minat anak untuk lebih senang dan giat belajar, bahkan dapat memudahkan anak dalam memahami materi ajar yang disampaikan.

- Anak dibuat senang, tidak bosan, dan tertarik dalam mengikuti proses pembelajaran

Lagu yang digunakan disesuaikan dengan materi pelajaran. Materi yang diajarkan pada saat ini bagian tubuh dan lagu yang digunakan adalah lagu kepalapundak-lutut-kaki versi bahasa inggris. Anak-anak sangat menikmati lagu ini karena mereka pernah mendapatkannya di taman kanak-kanak. Langkah - langkah dalam pembelajaran kosakata bahasa inggris menggunakan lagu adalah : 
- Anak-anak mendengarkan lagu

- Sambil mendengarkan mereka memperhatikan bagian yang di pegang sesuai dengan lagu

- Setelah itu, lagu di matikan dan praktik bersama

- Dengan menggunakan lagu ini, anak-anak terlihat lebih menguasai kosakata dan mereka lebih cepat dalam mengingatnya.

4. Flashcard

Flash cards merupakan kartu kecil yang berisi gambar, teks, atau tanda simbol yang mengingatkan atau menuntun siswa kepada sesuatu yang berhubungan dengan gambargambar yang dapat digunakan untuk melatih mengeja dan memperkaya kosakata (Arsyad, 2011). Flash cards memiliki dua sisi, bagian depan flash cards terdapat gambar dan kata sedangkan bagian belakang flash cards merupakan arti kata tersebut.

Tahapan dalam menggunakan flashcard adalah :

- Siswa mendengarkan penjelasan dari guru

- Guru mengacak gambar beserta artinya

- Siswa merebut untuk mencari pasangan antara kosakata dan gambar agar sesuai

\section{KESIMPULAN}

Hasil penelitian menunjukan bahwa melalui kegiatan home visit anak-anak mempunyai ketertarikan untuk belajar bahasa inggris. Anak-anak terasa mudah untuk mengingat kosakata yang mereka sudah hafalkan dengan menggunakan metode yang menyenangkan daripada anakanak harus menghafalkan kosakata.

Namun, guru bahasa inggris juga harus mampu merancang proses pembelajaran yang menarik. Ini bertujuan untuk membuat anak-anak merasa menikmati, antusias, dan lebih tertarik untuk mengikuti proses pembelajaran. Guru bahasa inggris harus mampu merancang yang menarik yang sesuai dengan kebutuhan anak-anak.

\section{SARAN}

Kegiatan belajar bahasa inggris bersama sangat diperlukan oleh anak-anak apalagi dengan menggunakan metode yang menyenangkan sehingga anak-anak tidak merasa bosan. Perlu adanya metode baru untuk meningkat minat belajar bahasa inggris anak-anak.

\section{UCAPAN TERIMA KASIH}

Ucapan terima kasih terutama ditujukan kepada segenap pengurus beserta Kepala Madrasah dan jajaran guru MI NU Rowolaku yang telah mendukung terlaksanaanya program pengabdian ini. Tak lupa juga untuk anak-anak yang sudah terlibat mengikuti program ini.

\section{REFERENSI}

[1] Basuki, S. (2020). Model Penugasan Belajar di Rumah Yang Menyenangkan Bagi Siswa di Masa Pandemi COVID-19. Jurnal Pendidikan Dasar Nusantara, 199210.

[2] Dewantari, K. A. (2020). Pendampigan Belajar Pada Masa Pandemi Berbasis Dongeng Untuk Meingkatkan Kemampuan Berfikir Sola. Jurnal Pengabdian Kepada Masyarakat, 72-79.

[3] Dewi Puspitasari, Wiwien Widya Rahayu, Rohmatunazilah, Suwarno. (2020). Mengeksplorasi Perasaan Mahasiswa Internasional:Saat Kita Belajar secara Virtual selama Pandemi COVID-19. Open Journal In Education, 143.

[4] Eka Agustina, Ainur Rohmah, Hastuti Retno Kuspiyah. (2019). Pendampingan Bimbingan Belajar Bahasa Inggris dan Bakti Sosial di Yayasan Pendidikan dan Sosial Roudlotut Thullab. Jurnal Indonesia Mengabdi, 1-5. 
[5] Elly Syahadati, Citra Kusumaningsih, Finny Anita, Agung Drajat. (2020). Pendampingan Belajar Bahasa Inggris Menggunakan Media Interaktif Bagi Anak-anak Di Panti Asuhan Uswatun Khasanah Pontianak. Jurnal Pengabdian Kepada Masyarakat, 159-166.

[6] Harmer, J. (2007). The Practice of English Language Teaching (4th $E d$.). Essex: Pearson Longman.

[7] Hebert, A. (2010). The Pedagogy of Creativity. New York:: Rouletge Taylor and Pancis Group.

[8] N. W. S. Damayanti, I Nengah Suecaca, Linda Sekar Utami. (2020). Pendampingan Bimbingan Belajar Di Rumah Siswa SD Dusun Buruan Tampak Siring Untuk Menumbuhkan Motivasi Belajar Siswa. Jurnal Pengabdian Masyarakat Berkemajuan, 2072010.

[9] Pinter. (2011). Children learning second language . London: Palgrave Macmilan.

[10] Sajarwo dan Akhirudin. (2020). Pendampingan Pembelajaran Ekstrakulikuler Bahasa Inggris Siswa Dalam Menghadapi Revolusi Industri 4.0 Pada Sekolah Dasar Inpres Gowa. Membangun Negeri, 55-65.

[11] Sartika, R. (2017). Implementing World Wall Strategy In Teaching Writing Descriptive Text For Junior High School Students. Journal Of English and Education, 179-186.

[12] Siregar, M. I. (2018). Pendambingan Belajar Siswa Di Rumah Melalui Kegiatan Bimbingan Belajar Di Desa Guci Karanggeneng Lamongan. Jurnal Abdimas Mandiri, 19-23.

[13] Sri Endang Kusmayati, Slamet Utomo, Titis Sulistyowati. (2019). Pendampingan Pembelajaran Kosakata Bahasa Inggris Bagi
Siswa SD 2 Panjang Kudus Dengan Permainan Guessing Games. Muria Jurnal Layanan Masyarakat, 2832.

[14] Tri Handayani, Hariyani Nur Khasana,Rolisda Yosintha. (2020). Pendampingan Belajar Di Rumah Bagi Siswa Sekolah Dasar Tedampak CVID-19. Jurnal Pengabdian Kepada Masyarakat, 107-115. 